\title{
ON THE MORPHOLOGICAL "VARIATION" ON THE AEDAEGUS OF Schizotetranychus oryzae (ACARI, PRCSTIGMATA, TETRANYCHIDAE) .*
}

Carlos H.W. Flechtmann**

\section{RHSUMO}

Sobre a "variação" morfológica do edéago de ichizotetranychusi oryzat (Acari, Pros tigmata, Tetranychidae).

Apresenta-se uma nota sobre a ocorréncia do àcaro do arroz, Sehizotetranychus ory zade Rossi de Simons, No Brasil, com observações sobre a "variação" morfológica do edéago do macho desta espécie de àca ro.

* Entregue para publicação em 07/03/85.

** Professor Titular - Dept? de Zoologia, ESALQ/USP. 
Anais da E.S.A. 'Luiz de Queiroz"

Schizotetranychus oryzae Rossi de Simons, 1966 Rev. Investig. Agrop., INTA, Ser. 5, 3(1):1-10.

S. oryzae, a potential pest of rice (Oryza sativa L.) was described from Corrientes, Argentina and from Rio Grande do Sul, Brasil. ROSSETO et alii (1971) reported it from the State of São Paulo and BARCELLOS et alii (1979) in the States of Rio de Janeiro and Espirito Santo, Brasil.

Outbreaks of this mite have been observed during dry spells, in the rice culture, infested leaves present small chlorotic areas visible from above; a certain amount of webbing on the lower leaf surface.

From material collected in Rio de Janeiro and Espirito Santo and from a recent outbreak in Santa Fë do Sul, São Paulo, several microscopic preparations were made and examined. The specimens agreed in all morphological aspects with the original description given by Rossi de Simons, except in the shape of the aedaeagus. Since characteristics of the aedaeagus are the most important single male characters and since many published figures suggest the possibility that the variability results from viewing the aedaeagus at angles not quite perpendicular to the median plane (BOUDREAUX $\&$ DOSSE, 1963), several males were studied and their aedaeagi figured.

Figures 1 and 4 were obtained from near perfect. lateral mountings, which clearly.indicate that the axis of the stem of the aedaeagus is at a right angle to the axis of shaft; figures 2,3 and 5 represent the aedaeagus of S.oryzae as seen in a somewhat tilted position, which is supposed to be the one given in the original description. 

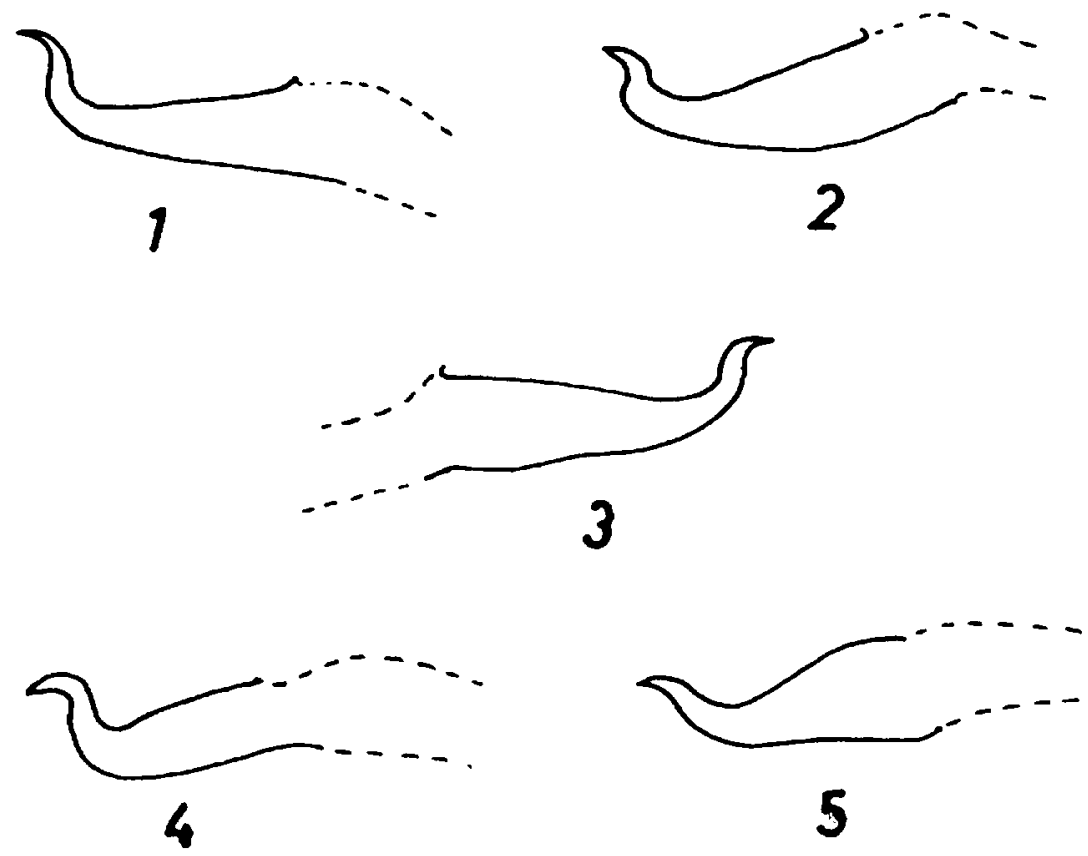

Figures 1 - 5. Schizotetranuchus oryzae Rossi de Somons, male, aedeagi. 1,4 - in near perfect lateral view; $2,3,5$ - in lateral but somewhat tilted position. 
Anais da E.S.A. "Luiz de Queiroz"'

\section{LITERATURE CITED}

BARCELLOS, D.F.; A.M. OLIVEIRA; S. SUDO; A.B. OLIVEIRA \& C.H.W. FLECHTMANN, 1979. Ocorrēncia do Acaro do Arroz nos Estados do Rio de Janeiro e Espírito Santo. Pesq. Agropec. Brasil., Brasília, 14(2):181-184.

BOUDREAUX, H.B. \& G. DOSSE, 1963. The usefulness of new taxonomic characters in females of the genus Tetranychus Dufour. Acarologia 5(1):13-33.

ROSSETO, C.J.; S. SILVEIRA N.; D. LINK, J. GRAZIA-VIEIRA; E. AMANTE, D.M. SOUZA, N.V. BANZATTO \& A.M. OLIVEIRA, 1971. Pragas do irroz no Brasil. In: Contri buiçōes tēcnicas da delegação brasileirăà 2ạ Reunião do Comi tê do Arroz da Comissão Internacional do Arroz da F.A.O., M.A./DNPEA, p.149-238.

ROSSI DE SIMONS, N.H., 1966. Descripción de Schizotetra nychus oryzae sp.n. (Acari, Tetranychidae). Rev. Investig. Agropec., INTA, Buenos Aires, Ser. 5, 3(1): $1-10$. 